\title{
THE AUSTRIAN SOCIAL FESTIVAL KEEP THE BALL ROLLING IN A PERIPHERAL REGION OF UPPER STYRIA
}

\author{
Isabell Gstach ${ }^{1}$
}

Received 26 November 2012; Accepted 20 September 2013

\begin{abstract}
The "Steirische Eisenstraße" is a region located in the province of Styria in Austria, which has been struggling with a massive shift in population and age structure for some time. In 2012/13 the Austrian social festival Keep the Ball Rolling is taking place in this region. Over a period of 18 months, the social festival is providing opportunities to think of their own environment. Consequently, they can develop and implement ideas for good cohabitation and put these into practice. The main focus of this article is the demographic presentation of the "Steirische Eisenstraße" region, according to population, employment and age structure. The introduction of the social festival is fundamental in initiating successful change processes.
\end{abstract}

Key words: Steirische Eisenstraße, Keep the Ball Rolling, social festival, demographic change, public participation, bottom-up

Zusammenfassung: Die „Steirische Eisenstraße“ ist eine Region in der Obersteiermark in Österreich, welche seit geraumer Zeit mit Veränderungen der Bevölkerungszahlen und der Altersstruktur konfrontiert ist. Innerhalb dieser Region findet 2012/13 das österreichische Sozialfestival Tu was, dann tut sich was. statt. Das Sozialfestival gibt der lokalen Bevölkerung für 18 Monate die Möglichkeit über die eigene Umgebung nachzudenken und Ideen für ein besseres Zusammenleben zu entwickeln und umzusetzen. Im Zentrum des vorliegenden Beitrages steht einerseits die demografische Darstellung der Region „Steirische Eisenstraße“, in Bezug auf die Fakten Bevölkerung, Beschäftigung und Alter. Andererseits wird das Sozialfestival als Beispiel für eine neue Form der bürgerlichen Beteiligung betrachtet, welche für eine positive Umgestaltung, in einer sich verändernden Region, wesentlich erscheint.

\section{Introduction and hypotheses}

The demographic trend in Austria has gained much attention in the past few years. Primarily, the decline in the birth rate, respectively the change of age structure, is leading to problems for the pension security system, the welfare system and age-care services. The consequences of the demographic trend have also brought change at the local level, particularly in the problem of population decrease. The peripheral and structurally weak regions in Austria have to deal not

\footnotetext{
${ }^{1}$ Research fellow; International research centre for social and ethical questions (ifz) Salzburg; e-mail: igstach@ifzsalzburg.at
} 
only with a decline in population, but also with the consequences for e.g. public transport, old age care, disappearing job market. For example, the existing infrastructures such as public transport and/or social facilities would have to be maintained with declining financial resources. A decline in population includes a reduction in social contacts for the local residents. Social contacts are important for effective cooperation, for shared experiences and building societal structures.

Due to the complexity of demographic change to all aspects of daily life, various areas of research, ranging from demography and sociology to political and regional sciences have shown interest in demographic characteristics and the consequences of these changes.

Problems, resulting from demographic change, cannot be solved solely on a political level. The local population in peripheral and structurally weak regions, as well as local knowledge becomes vitally important for maintaining the local infrastructures. Clubs, associations and other forms of public participation make important contribution to varying solutions for problems resulting from demographic change.

The fundamental idea of the social festival Keep the Ball Rolling, which takes place in the "Steirische Eisenstraße" ("Styrian Irontrail") region in 2012/13, is to strengthen peripheral and structurally weak regions through public participation. The social festival was initiated by the Austrian theologian and philosopher Clemens Sedmak and launched 2010 in the Lungau region in the province of Salzburg/Austria. It is a project inspired by existing projects, such as European Capitals of Culture.

The phrase - social festival - is unusual in this context, as the time frame for other festivals is typically limited to a few days. However, the goal of the social festival is to celebrate the local community and the interaction - not just for a few days, but for eighteen months. "The festival focuses on social matters, and on supporting people who want to create fruitful and sustainable conditions for living together in a good way and also to foster social cohesion." (Kapferer 2012: 59)

These points lead to the two hypothesis of this article:

- In addition to clubs, societies and associations, other forms of public participation, such as Keep the Ball Rolling, realize an important contribution in maintaining a local community in regards to demographic change

- The social festival Keep the Ball Rolling enables the local population to get involved with the consequences resulting from demographic change and to develop effective solutions.

The first part of this report presents a review of the "Steirische Eisenstraße" demographic characteristics, which then influence social and economic change. This description provides an insight in to the existing problems of the region.

In the second part of this report, various basic ideas regarding Keep the Ball Rolling are presented, such as the festival being an example of active citizenship. People in demographically challenged regions should be motivated into participating in increasing better living quality. Within the festival cycle, local residents realize their ability to submit projects relating to three major issues. These issues are "good community life", "good working and business conditions" and "good poverty alleviation". The background of this social festival will be investigated in this paper.

Finally, in merging the two main topics - the social festival and demographic change the question arises as to how the social festival can contribute to alleviating demographic and social problems. This question, including the two hypotheses, will be discussed in the last portion of the report.

\subsection{Research Background}

The basis of this paper is the scientific monitoring of the social festival-project Keep the Ball Rolling (Tu was, dann tut sich was.), which in 2012/13 takes place in the "Steirische 
Eisenstraße" region. This region is part of the Leoben district in the Austrian province of Styria, which has been confronted with a distinct demographic shift.

As part of the scientific monitoring of the social festival, a multidisciplinary team of researchers have been analysing the social festival from the perspectives of poverty research and methodical social geography. The scientific research comprises the analysis of the social festival's impact on peripheral regions. The survey of the data includes a mix of methods. Within the first step of the research, the local participants of the social festival were interviewed via telephone with a semi-standardized questionnaire. Moreover, a workshop within the region was held. The last step comprised of deepening individual interviews as well as group discussions with participants. The emphasis was placed on developing social networks within the social festival, the social festival's contribution in the region from the participant's point of view and fostering social cohesion.

The data presented in the following report was accumulated in context with the social scientific research.

\section{The region "Steirische Eisenstraße"}

The first part of this chapter deals with facts concerning the region "Steirische Eisenstraße", putting special emphasis on the Leoben district, by focusing on location, population, employment and age structure.

The "Steirische Eisenstraße" region is situated in Upper Styria and is part of the Leoben district. The Leoben district is one of the 13 districts of Styria. The city of Leoben, the second largest in Styria, is the economic centre, with the Voestalpine Steel AG company (production of steel), Gösser (brewery), Mayr-Melnhof (timber and sawmills) and the University of Mining (Montanuniversität Leoben) being the most important regional employers.

\subsection{Population - „Steirische Eisenstraße“}

Styria has benefited from a consistent population growth since 1869 which continues through the present. The baby boom during the 1950's and the 60's was the major contributor to this population increase. Styria has always demonstrated negative values in regards to migration balance. However, it was possible to avoid a population decrease in the '70's through the baby boom years. (cf. Redik 2002: 238f)

Likewise, the Leoben district, and therefore also the "Steirische Eisenstraße", demonstrated a continuous population growth of 143\% from 1869 through 1971 - a period of more than one hundred years. The first signs of a slump in population increase in the Leoben district occurred between 1923 through 1934, which, among other factors, can probably be attributed to the global economic crash which transpired during this time. Consistent population decrease took place in the '70's and is continuing today. This unfortunate development can be explained through job scarcity due to an economic slump in industry within the region. (cf. Steiner 2002: 15) This problem will be addressed in detail in the chapter "Employment".

According to the census from 1971, the population in the Leoben district has decreased $22 \%$ until 2012. (cf. Statistics Austria Leoben 2012) Figure 1 illustrates this trend. 


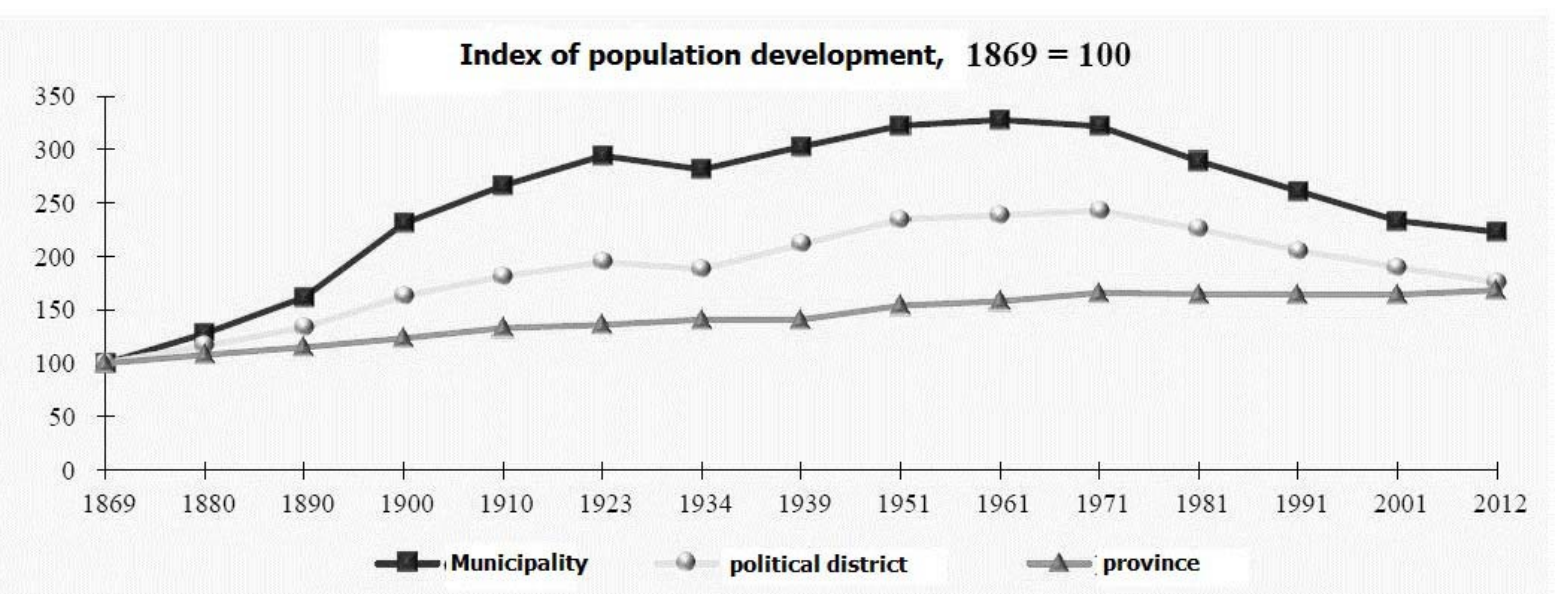

Fig 1. Population development Styria, Leoben district, municipality Leoben 1869 - 2012 Source: Statistics Austria, Leoben, population census 2012; revised by author.

The population forecast for the Leoben district shows a further decrease of nearly $14 \%$ from 2010 until 2050. Figure 2 below illustrates this trend in comparison to Austria, respectively Styria.

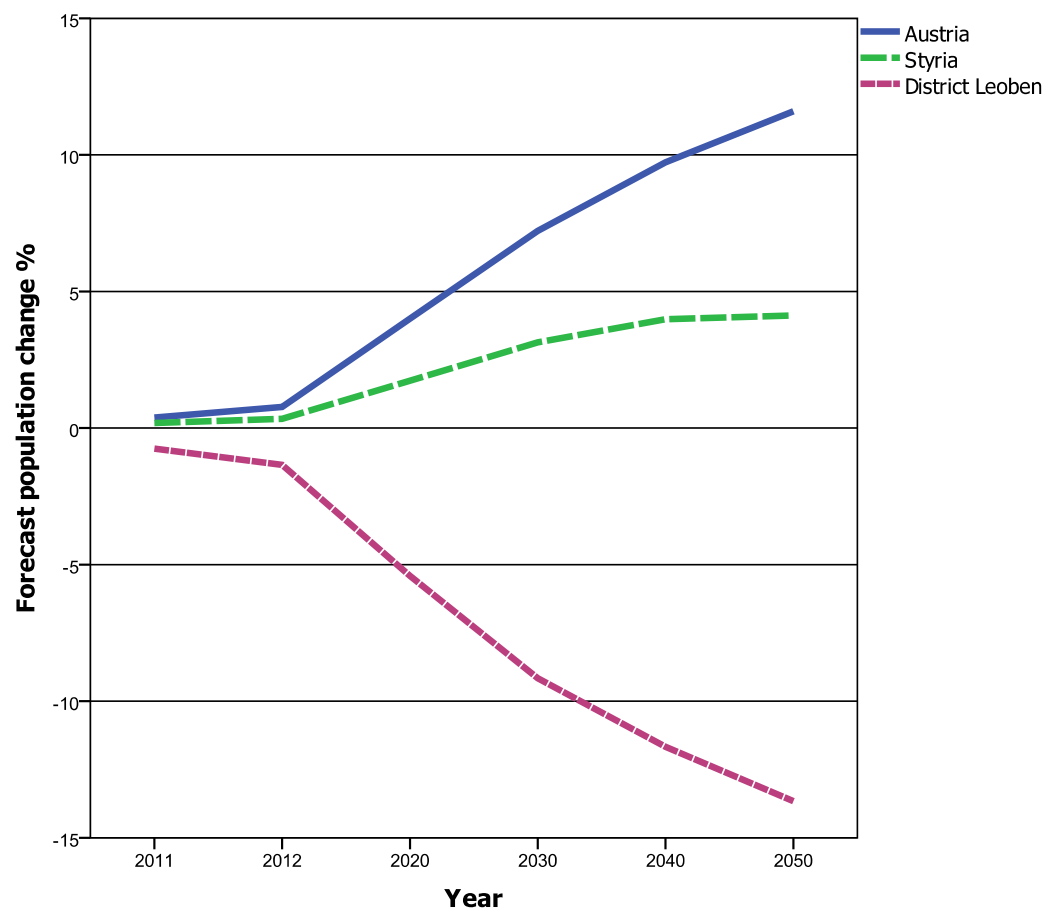

Fig 2. Forecast population development Austria, Styria and Leoben 2010 - 2050. Source: Statistics Austria, 2011; Statistics Styria, 2010: 38; design: Isabell Gstach 2012.

In a more detailed view within the Leoben district, only four municipalities show a very high population decrease predictions until 2030. These four communities are Eisenerz, Vordernberg, Hieflau and Radmer. (cf. Statistics Styria 2010: 80) (Figure 3) The most pronounced decrease in population was seen in Vordernberg.

Since 1961 and continuing through 2012, a constant population decrease has established itself in all four regions, with only Eisenerz as an exception. The trend towards a decreasing population began in Eisenerz in 1951. 


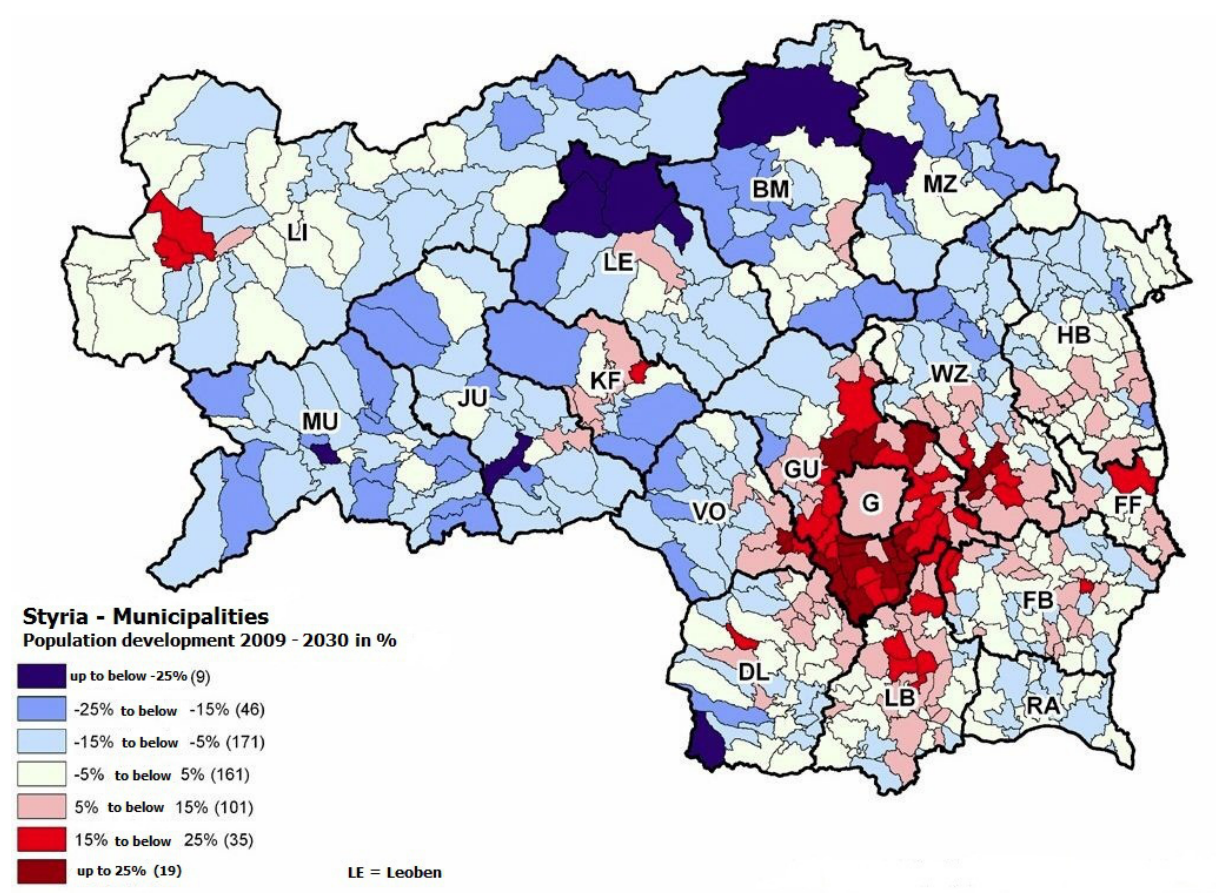

Fig 3. Population development of the communities 2009 to 2030. Source: Statistic Austria; Adaption: Statistic Styria, 2010: 80; revised by author.

In closing, the foreign population data has to be clarified. Based on data from 2012, $7.2 \%$ of international immigrants $(87,713$ persons) live in the province of Styria. This value is slightly lower than the national average (11.5\%). However, a detailed view shows that, out of these $7.2 \%, 6.6 \%$ or 5,972 immigrants are living in the Leoben district. (cf. Statistics Austria 2012: $258 \mathrm{ff})$ Nevertheless, nearly $48 \%$ of these 5,972 persons are located in the city of Leoben, and only $2.8 \%$ live in Eisenerz.

\subsection{Age structure}

The age structure of the region has also changed since 1981. In 1981, the values of the up to 14-year-olds and 61+ year-olds reached parity. The Leoben district was one of the "younger" districts, due to the birth surplus and the economic boom after the reconstruction phase of the 1950's. As a result of economic difficulties during the 1970's and 1980's youth transmigration increased. Today, the population of Leoben district is demographically one of the oldest within the province of Styria. (cf. Redik 2002: 256) Figure 4 shows this development.

The age structure of "Steirische Eisenstraße" will also shift upwards in the future. Figures 5 and 6 show the forecasted development of the age structure from 2009 to 2050 . The consequences of the low-birth years are, in total, more noticeable in Styria than in the Leoben district. The change from 2009 to 2050 in the 65-year-old age range is higher in Styria than in the Leoben district, and the movement of the up to 19-year-olds is much lower. One reason for this trend is shown in the basic values from 2009. These figures are higher for the 65-year-olds respectively lower for the 19-years-old in 2009, within the Leoben district, as illustrated in Figures 5 and 6. (cf. Statistik Austria 2011)

Furthermore, the prognosis for the province of Styria is that the municipality Eisenerz will be under the top ten municipalities in the Styrian area, with the lowest number of up to 19-year-olds until 2030, and under the top ten with the highest proportion of 65+ year-olds. In comparison to Austria, the 65+ year-olds would account for a nearly 15\% increase in Eisenerz until 2030. (Austria: 2030 - 23.6\%; Eisenerz: 2030 - 38.2\%) (cf. Styria Statistic; Statistic Austria 2010) 


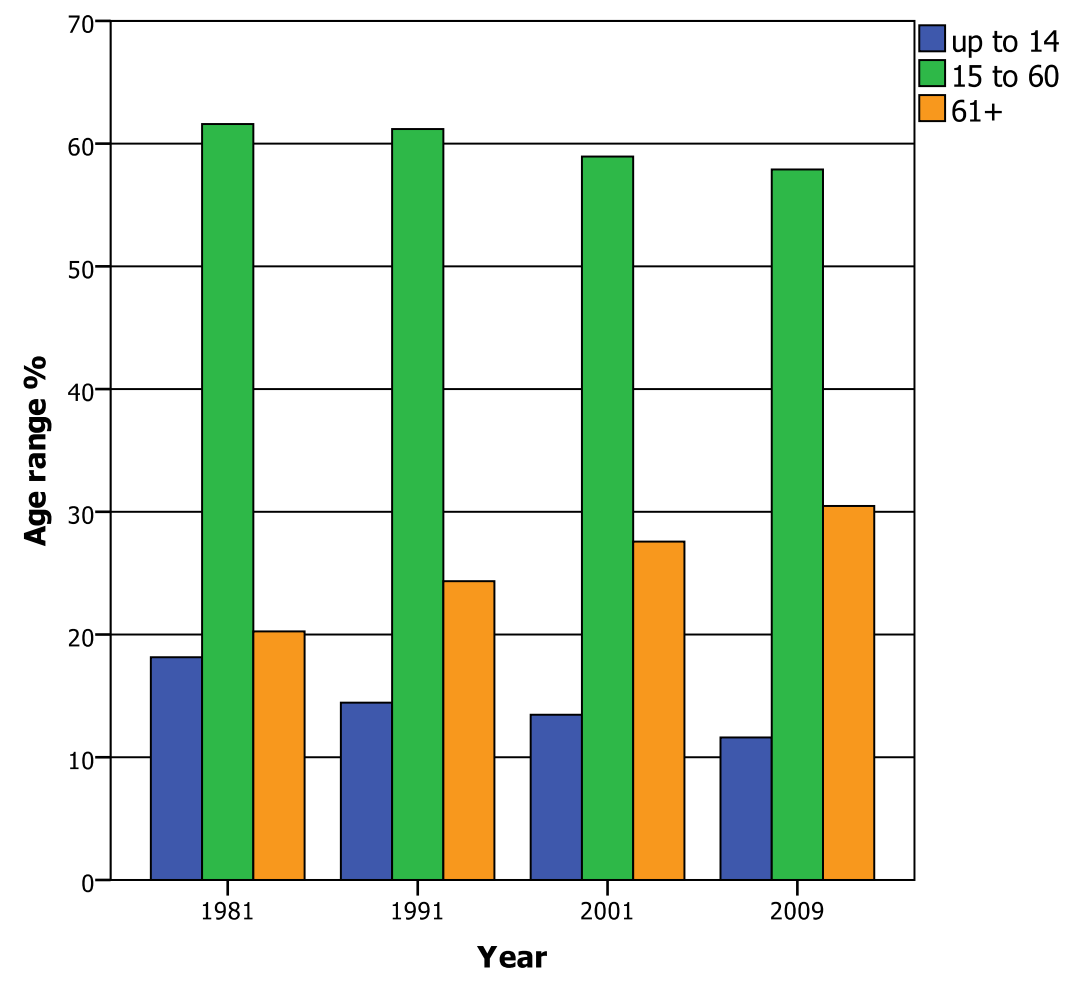

Fig 4. Age structure 1981 to 2009 - Leoben district. Source: Statistic Styria, Leoben, 2012; design: Isabell Gstach, 2012.

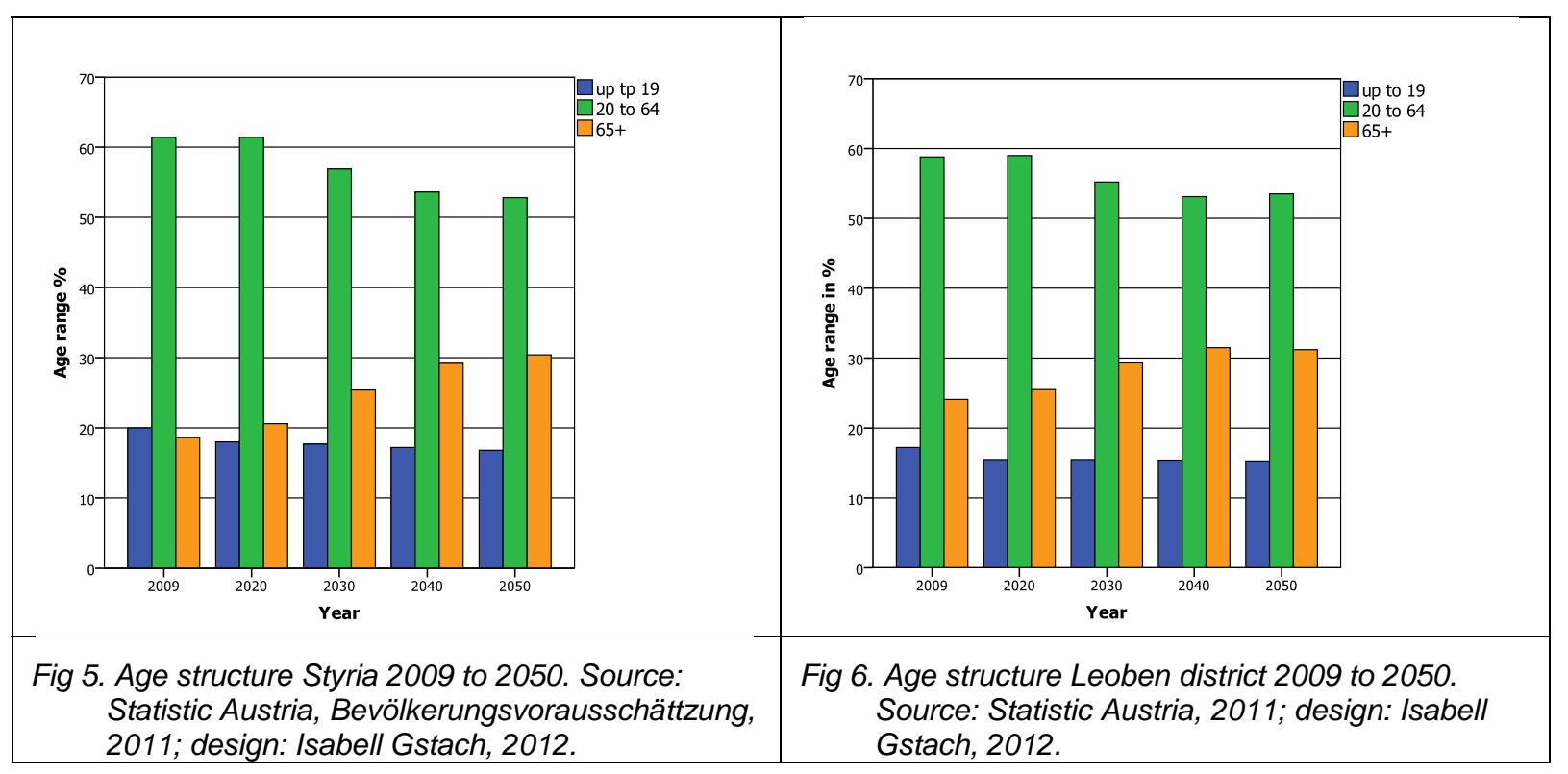

\subsection{Employment}

Before 1960, macroeconomic demand in Styria concentrated itself primarily on raw materials, (wood, iron, ore, etc.). Styria's industry enjoyed a boom in the course of expansion. As of the early 1960's, a shift in focus from raw materials to end production became evident. This shift led to a demand for new technologies and more innovation, resulting in diverse adaption problems for Styrian businesses. Styria was not prepared for such challenges. (cf. Steiner 2002: 146)

In the 1970's, many of the larger companies in Upper Styia, and consequently in the Leoben district were nationalised. During this time, practically every third employee was employed in a nationalised company. Alongside an increase in raw oil prices in 1970, 1979 and 1980, other factors including company size, sluggish decision making, and production based on raw 
material led to a financial crisis. Most notably larger companies, such as Voestalpine and Erzberg, gave notice to a disproportionate number of employees from 1971 to 1991. (cf. Steiner 2002: 131; 151)

In 1960, nearly 4,000 employees were employed in the mining industry there. However, in 1970, foreign ore, which had much higher iron content, led the Eisenerz mining industry into crisis. (cf. Brodda/Heintel 2009: 318) In 1986, the state-owned company Voestalpine initiated a high redundancy policy. By the later part of the 1990s, only 340 employees were working at the Erzberg mine. The decrease was also partly due to technical processes. (cf. Moser/Graf 1997: 251) From 1981 to 1991, the unemployment rate of Eisenerz changed from 3.7\% to 12.1\%. In 2009 the unemployment rate was 7.8\%. (cf. Statistics Styria 2012)

Another similar example is the renowned Voestalpine Steel AG Company (production of steel), situated in Leoben-Donawitz. In 1978 the company employed 6,700 persons, but reduced its employee stand to 1,800 in the 1990's. (cf. Steiner 2002: 154f)

As in Eisenerz, the unemployment rate for the city of Leoben increased from $3.9 \%$ in 1981 , to $10.7 \%$ in 1991 . The consequence of this change resulted in an on-going decline of population, long-lasting unemployment and a higher quota of early retirements, as well as higher unemployment among the elderly (cf. Steiner 2002: 155) Even in 2009, the unemployment rate for the "Steirische Eisenstraße" region was 7.3\%. In comparison, the unemployment rate for Styria was 4.6\% in 2009. (cf. Statistic Austria 2010: 262)

Today, Leoben district is attempting to make the region more attractive for visitors, as the following data will point out. The focus is placed on moving from the industry, manufacturing and construction sector (1981: 49.9\%; 2009: 30.0\%) to services (1981: 45.6\%; 2009: 66.3\%). A decrease of $19.9 \%$ in the industry sector took place from 1981 to 2009 . The primary sector agriculture was of little importance for the region in 1980 and 2009. (1981: 4.4\%; 2009: 3.7\%) (cf. Statistic Styria Leoben 2012)

\subsection{Consequences}

With respect to the above stated demographic facts regarding the "Steirische Eisenstraße" region, two things should be kept in mind. First, it can be shown that the consequences of the population development and age structures vary within the region. It is well-known that population development depends upon various facts, such as labour market, institutional framework conditions, transport infrastructure, landscape attractiveness, and dwelling or recreational values (cf. Gans / Schmitz-Veltin 2005: 111f). For example, as Eisenerz is situated between the national park Gesäuse and the Präbichl, a mountain which divides Eisenerz from other parts of the Leoben district including the district capital, infrastructural problems are evident. Transport infrastructure is an important reason for company location or relocation. These factors, among others, motivate or discourage people to stay within a region or to leave. Eisenerz has noticeable problems concerning emigration and employment, as well as to an unfavourable location. Population has been decreasing steadily since 1951, showing these problems have existed for a long time.

Secondly, it should also be mentioned that, although the city of Leoben has a well-connected infrastructure, large companies such as Voestalpine Steel AG, Göss brewery or Mayr-Melnhof, it experiences problems due to the higher proportion of immigrants in comparison with other municipalities in the region.

Consequently, regional planning within the area has to be applied in different ways: either against or with the consequences of demographic change. However, every change on a regional level must be agreed upon and participated in by the local residents. One of the biggest problems in the region is that for many years inhabitants have defined and identified themselves with iron and ore through their employment. The industrial sector, particularly raw material industry, created an identity for the people in this region. (cf. Moser / Graf 1997: 248) New technologies and innovation, competition, globalisation and various other factors led to a shift towards job rationalisation. As a result, identity created through employment in these 
industries increasingly lost in merit. The question arises how to establish an identity based on other facts than employment.

Clubs and associations provide an opportunity for local residents to participate, respectively to construct their social networks and beyond that, their identity. However, long-term commitment and membership are not attractive to all people.

Moreover, looking towards the future, it should be mentioned that a steady decrease in population would effect a noticeable reduction in social structures, to the point that they could ultimately vanish entirely. Clubs and associations, for example, which promote identity through association, and broaden the network of each individual player, could also be drastically reduced in these regions. Under these circumstances, many organisations would be forced to dissolve due to lack of membership. What remains in the end? An initiative such as the social festival Keep the Ball Rolling could motivate people to interact, to strengthen the awareness of a region and to strengthen social networks.

Therefore it attempts to show on which level the social festival can play a role in contributing to a better lifestyle, taking into account the consequences of demographic change. The following part of this article will deal with the festival approach, the starting point and will present a few results of the scientific monitoring.

\section{Keep the Ball Rolling. The social festival approach}

The concept of the social festival is to use local knowledge to bring about structural change with a view to enable a good lifestyle. Everyone has different social backgrounds and different ideas for changing situations. The essential point is the bottom-up approach; meaning that individuals are called to give their thoughts to problems, wishes and perspectives for the future of their own environment. (cf. Kapferer 2012: 59)

One main idea of the social festival is in keeping with the Gross National Happiness Index of Bhutan. In connection with Keep the Ball Rolling, this guiding vision shows that to people within a region, happiness is more important than money. Money for its own sake does not create happiness. Relationships, solidarity, creativity and innovations are factors which contribute largely to better living. (cf. Sedmak 2012: 21)

The initiator of the social festival (Clemens Sedmak - theologian and philosopher) formulated nine theses for social cohesion. He asserted that people of a region should think about what kind of society or community they wanted to be part of. They should define the capabilities and resources of the area. The quality of the structure of public space (social, cultural and moral framing conditions of our lifestyle) should also be kept in mind. Human identity grows through relationships, collective experiences and shared memories which fix the sense of belonging. When people have more self-esteem, they then have more self-confidence in the idea that they could bring about change. If people of a region think about good lifestyles and a better society, the question of exclusion must also be answered; exclusion due to a lack of economic resources and through segregation. In conclusion, communities have to think about shared values. (cf. Sedmak 2012: 18ff)

\subsection{The Starting Point}

One of the slogans of the social festival is "A good way of cooperating is the key for a good life; therefore you need trust and respect for each other." (Sedmak 2012: 6; translation I. G.).

The Austrian social festival was launched in December 2010 in Lungau - a region in the province of Salzburg. The festival was promoted by a local community organisation/regional office, in cooperation with the international centre for social and ethical questions (ifz) in Salzburg. This centre also undertakes the social festvial's scientific research. The social festival cycle is one and a half years. Within this time, local residents obtain the chance to submit projects relating to three major issues like "good community life", "good working and business conditions" and "good poverty alleviation". All in all, 120 projects were submitted and presented to a jury, and of these, almost 70 projects were selected and have since been put into practice in Lungau. (cf. Kapferer 2012: 60) 
A number of private Austrian foundations, which make up the "SinnStifter" ("meaningful project sponsors") organisation, sponsored the social festival.

As mentioned previously, Keep the Ball Rolling is scientifically assisted. Multidisciplinary researchers investigate the impact the social festival could have within a region. In line with this research, the central theme revolves around building regional identity and promoting regional social networks on the strength of the social festival. Similar to the "Steirische Eisenstraße", the Lungau region has also been confronted with a distinct demographic shift. Many young people are forced to become commuters in order to maintain employment, and many students leave the Lungau in order to study, as the region itself lacks universities or other (academic) institutions or higher education. Consequently, these regions are confronted with the problems of not only a decreasing birth rate, but also an increase in an aging society. "On a low level basis, the social festival, Keep the Ball Rolling, can encourage public perception of the region and support the formation of regional identity." (Kühn / Koch 2012: 120; translation I.G.)

\subsection{Keep the Ball Rolling's Contribution in the "Steirische Eisenstraße" Region}

In 2012/13 the social festival was conducted in the "Steirische Eisenstraße". Again, local residents were able to submit projects relating to the three major issues mentioned above.

In this region, a total of 107 projects were submitted, 96 having been presented to a jury, 65 were selected and have since been put into practice. Out of these 107 projects, 28 projects respectively $26 \%$, were proposed by residents of the four communities with the highest population decline - Eisenerz, Hieflau, Vordernberg, Radmer (see chapter 2.1, figure 3).

\subsubsection{Scientific assistance provides feedback for the region}

As a part of the social festival's scientific monitoring, 72 project submitters were interviewed via telephone, using questions from a semi-standardized questionnaire made up of 27 questions. They were requested to inform the researchers about their social networks, as well as their views and attitudes towards the "Steirische Eisenstraße" region. Table 1 shows the main questions within the survey, which were relevant for this paper.

Moreover, a workshop was held for the project submitters, which was attended by 31 local participants in the festival. The participants had the possibility to discuss current topics regarding their current and future well-being. The results of this discussion provide insight into the opinions of the local residents.

As previously mentioned, the scientific research is work in progress and still incomplete at the time of writing. In addition to the telephone interviews and workshop which have been concluded, individual interviews and group discussions with the project submitters are still in progress. The finalized analysis of the questionnaire and the individual interviews as well as a comparative analysis of Lungau and "Steirische Eisenstraße" will be central to a forthcoming publication in autumn 2013.

\begin{tabular}{|ll|}
\hline - & What was your essential reason for participating in Keep the Ball Rolling? \\
\hline - & Are you an active member of a club or association? \\
\hline & Do you think, the social festival could induce a middle- to long-term impact on the "Steirische \\
\hline - & How would you define the region? \\
\hline - & What are the characteristics of the region? \\
\hline - How would you describe the people of the region? \\
\hline - Do you feel a particularly connection to the region? \\
\hline
\end{tabular}

Tab 1. Questions for telephone interviews.

The last part of this report discusses the social festival's contribution towards alleviating the problems of demographic change in the "Steirische Eisenstraße" region. 


\subsubsection{Contribution in finding solutions for problems resulting from demographic change}

A more detailed view into the 107 submitted projects highlights a large amount of topics that local residents are dealing with - integration, developing social capital, generation-gap, regional awareness, demographic change, community and inclusion of socially disadvantaged groups.

An analysis of the 107 individual projects in the "Steirische Eisenstraße" showed clearly that there was little need to point out the fact of "demographic change" and its impact on the local resident. Most of the local people were well aware of the demographic change issues. They are already involved in searching for solutions for the problems resulting from demographic change, such as lack of integration, generation-gap and lack of social capital. Consequently, Keep the Ball Rolling could help to increase the awareness of the pressing regional problems. Preliminary findings based on a first analysis of the proposed project are summarized in Table 2. It presents more a matter of multiple choice, as the projects deal not necessarily with merely one theme, but in most cases, many themes.

\begin{tabular}{|l|c|}
\hline Socially disadvantaged groups / Inclusion & $\mathbf{3 3}$ \\
\hline Developing social capital & $\mathbf{3 2}$ \\
\hline Regional awareness & $\mathbf{2 8}$ \\
\hline Generation-gap & $\mathbf{2 0}$ \\
\hline Leisure & 14 \\
\hline Environmental behaviour / action & 13 \\
\hline Social responsibility & 10 \\
\hline Integration /Migration & 8 \\
\hline Culture & 8 \\
\hline Integrated interaction & 8 \\
\hline Demographic change & $\mathbf{7}$ \\
\hline Health & 5 \\
\hline Total & 186 \\
\hline
\end{tabular}

Tab 2. Topics in project applications "Steirische Eisenstraße" Source: 108 project applications February to May 2012; design: Isabell Gstach, 2012.

Table 2 illustrates that 33 projects deal with issues of inclusion of socially disadvantaged groups such as disabled/handicapped people, deprived youngsters and children and single parents. 32 projects concentrate on establishing social relationships and social capital. In addition, 28 projects focus on strengthening awareness of the region, and lastly 20 additional projects deal with generation-gap related problems. Only seven projects directly address the topic "demographic change". The goals of these seven projects are to point out the problems for the local residents resulting from a birth rate decline, changes in the age structures and regional migration. However, also projects dealing with other issues tackle questions of demographic change.

The generation-gaps related projects reflected the demographic situation in the region. As mentioned in chapter 2.2, in 2009 a generation imbalance within the Leoben district already existed between the up to 19-year-olds and the 65-year-olds. In 2009 17.2\% of Leoben's population consisted of up to 19 -year old, but $24.1 \%$ were already 65 -years old or older. Submitted projects dealing with the generation-gap, better interaction between those age groups e.g. by creating adequate space, more interaction between children and older people through visitation on part of the children and recounting regional experiences about their lives on the part of the older people.

Projects dealing with strengthening regional awareness and establishing social relationships, contribute to the attractiveness the regional environment. Subjective well-being could result due to this attractiveness. If people are aware of their environment, and if they are well embedded in their social networks, they would be more prepared to act together in groups to create effective solutions for regional problems. Such projects focus on contact between various groups (age, ethnic, social situation), and point out not only regional products, but the desire to ecologically friendly as well. 
An insight into the individual projects reflects the basic concept of Keep the Ball Rolling, as mentioned to the beginning of chapter 3 - people who interact well together and thereby creating a better community respectively society.

One final point should be mentioned regarding the context of the telephone interviews. Nearly $80 \%$, respectively 58 of the interviewed project submitters informed the researchers, that they were connected with the region through social relationships, family, nature and/or employment. In addition, 36\% responded that the awareness of the "Steirische Eisenstraße" region and the local population increased due to the social festival Keep the Ball Rolling.

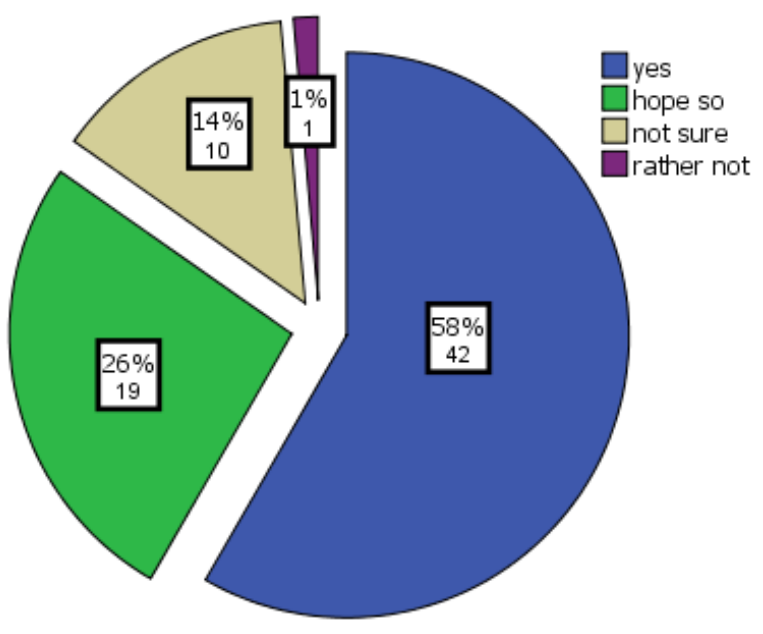

Fig 7. Impact of the social festival in the "Steirische Eisenstraße" region. Source: 72 telephone interviews May to November 2012; design: Isabell Gstach, 2012.

Figure 7 illustrates the interviewed people's opinions to the question: Could the social festival induce a middle- to long-term impact on the "Steirische Eisenstraße" region? Many of the 58\%, respectively 42 interviewees, who were confident of the social festival's impact, responded that the social festival would increase awareness of the region's problems, could strengthen selfconfidence, and also inspire people to participate and bring about change.

An important issue, with respect to demographic change in peripheral regions, is the reduction of existing infrastructures, such as social institutions and transportation facilities. Additionally, such regions are confronted with unoccupied buildings due to population migration and the changing age structure. Consequently, shops and restaurants begin to close, with the effect of further migration and vacant buildings. This situation results in a higher financial burden for the communities.

However, such problems cannot be solved solely on a political level. Residents have to be involved in finding a common basis for existing problems, and expanding the view of deficiencies in order to create suitable solutions for the local population. (cf. Lietzmann 2004: 296) In fact, that is the idea behind the social festival.

The social festival Keep the Ball Rolling could be one example for pointing out the willingness of local residents to become actively engaged in these issues. Residents are called upon to think about the problems and needs of their region. Due to this kind of participation, people receive the ability to expand their social networks and to stabilize their environment. The social festival works not just for individuals acting within clubs or associations, but for anyone wanting to submit a project and help to find effective solutions for the environment. An analysis of the question; is the project submitter an active member of a club or association, emphasized the fact of a low-threshold access participation. 33\%, or 24 of the interviewed people, were not involved in clubs with formal structures, but they did participate in the social festival.

Furthermore, Keep the Ball Rolling is based on voluntarism and could be seen as a new form of social participation. This type of engagement is increasingly significant, because people are 
now more interested in short-term, topic-based work groups than in clubs with a long-term or even lifelong membership. (cf. Gundert 2010: 110)

Voluntary commitment is important, because if a region is unable to engage people, change will not occur in a positive direction. In today's times, local policies need the thoughts and ideas of the local population to engage local resources. An additional goal of Keep the Ball Rolling is to develop a long-lasting relationship between infrastructures such as local governments or companies and local residents.

\section{Conclusion}

Any population prognosis should naturally be regarded with caution. Every change in the macro-level has an impact on the micro-level, and also produces feedback. If a region incurs problems due to demographic change, it becomes very important for politicians to involve local residents. As a result of the scientific study, half of the 72 interviewed people described themselves as being emotionally affiliated with the local landscape - mountains and valleys iron and agriculture, meaning that the traditions which shaped them are difficult to change. The history of this region formed the character of the people. Consequently, only the people of this area can affect a sustainable change.

In conclusion, a social festival such as Keep the Ball Rolling is able to strengthen the regional awareness and may enlarge the perspectives for regional problems. The submitted projects make contributions towards solutions for the problems caused by demographic changes, and the ensuing solutions should then be rapidly initiated. This report points out that projects play a key role in dealing with the creation and maintenance of social capital. In case of population decrease, it will become more important for the remaining residents to maintain regional relationships and intensify their social contacts. The submitted projects show this trend. Many of the projects deal with regional awareness, such as "producing a regional snack for pupils", "creation of an Eisenstraße scone" and "production of the Eisenstraße mix-orchard apple juice". In addition to these and many more, other projects concentrate on strengthening social contacts in order to minimize social exclusion and isolation.

Moreover, the social festival Keep the Ball Rolling encourages shared experience throughout the entire festival cycle, strengthens the participant's social networks, and motivates people to put ideas into practice. Finally, shared memories, hopes and experiences are, amongst other facts, basics for social cohesion and society. (cf. Sedmak / Fanninger / Suntinger 2012: 19)

Concerning the two basic hypotheses of this paper, in the case of demographic change, the social festival realizes an important contribution in maintaining local communities due to presentation of the individual projects. Keep the Ball Rolling refers not only to individuals who are already engaged in clubs or associations, but to the entire community. The second hypothesis that Keep the Ball Rolling enables a local population to become involved and then develop effective solutions was thoroughly verified.

The concept of the social festival as a whole provides the opportunity for residents in a specific region to think about the local problems resulting from: demographic change, weak community structures, or other forms of problems. The basic idea of the social festival is to motivate people to become active and participate. If motivation materialises, change on a micro-level and also on a macro-level could occur. The scientific monitoring, utilising a mix of methods, ensures feedback on various levels for the region. Additionally, an inter-regional comparison of Keep the Ball Rolling regions allows for effective development of the social festival. For the future, the scientific monitoring offers the opportunity to reflect upon regional problems in Austria even more deeply, as this research procedure would be continued in subsequent festival regions. 
[1] Brodda, Y., Heintel, M. (2009). Regionalentwicklung im Bereich inneralpiner Eisenindustrieund Bergbaustandorte. Das Beispiel der Eisenwurzen. In Hitz, H., Wohlschlägl, H., eds., Das östliche Österreich und benachbarte Regionen. Ein geographischer Exkursionsführer (pp. 313-332). Wien, Köln, Weimar: Böhlau Verlag.

[2] Gans, P., Schmitz-Veltin, A. (2005). Bevölkerungsentwicklung in ländlichen Gemeinden: Szenarien zu kleinräumigen Auswirkungen des demographischen Wandels. In Birg, H., ed., Auswirkungen der demographischen Alterung und der Bevölkerungsschrumpung auf Wirtschaft, Staat und Gesellschaft (pp. 111-129). Münster: Lit Verlag.

[3] Gundert, S. (2010). Bürgerschaftliches Engagement im ländlichen Raum. Das Beispiel Biedenkopf-Kombach: Zukunftschance trotz demographischen Wandels? Berlin: Springer.

[4] Kapferer, E. (2012). Making change happen: The Lungau Experience 2011. The social festival Keep the Ball Rolling from the perspective of poverty research. In Kapferer, E., Koch, A., Sedmak, C., eds., The Logics of Change: Poverty, Place, Identity and Social Transformation Mechanisms (pp. 58-75). Newcastle upon Tyne: Cambridge-Scholars.

[5] Kapferer, E., Koch, A., Kühn, N., Sedmak, C., eds. (2012). Sozialatlas Lungau. Ideen und Projekte für ein besseres Zusammenleben. Wien: Mandelbaum.

[6] Land Steiermark (2010). Steirische Statistiken. Heft 13. Landesstatistik Steiermark.

[7] Land Steiermark (2012). Landesstatisik Steiermark. Gemeinde- und Bezirksdaten. Eisenerz. (10.09.2012).

[8] Land Steiermark (2012). Landesstatisik Steiermark. Gemeinde- und Bezirksdaten. Leoben. http://www.verwaltung.steiermark.at/cms/beitrag/11680533/74837465 (10.09.2012).

[9] Land Steiermark (2012). Gemeinde- und Bezirksdaten. Gemeinderanglisten der Extremwerte. http://www.verwaltung.steiermark.at/cms/ziel/74835913/DE/ (24.09.2012).

[10] Lietzmann, Hans J. (2004). "Planungszellen" in einer älter werdenden Gesellschaft. Die Chancen der zivilgesellschaftlichen Gestaltung einer politischen Kontroverse. In Frevel, B., ed., Herausforderung demografischer Wandel (pp. 294-301). Wiesbaden: VS Verlag für Sozialwissenschaften.

[11] Moser, J., Graf, M. (1997). Zur symbolischen Bedeutung der Bergmannsarbeit in einer niedergehenden Bergbauregion. In Brednich, W., Schmitt, H., eds., Symbole. Zur Bedeutung der Zeichen in der Kultur (pp. 245-258). Münster: Waxmann.

[12] Redik, A. (2002): Die Bevölkerung der Steiermark seit 1945. In Ableitinger, A., Binder, D., eds., Geschichte der österreichischen Bundesländer seit 1945. Steiermark (pp. 235-277). Wien, Köln, Weimar: Böhlau Verlag..

[13] Sedmak, C. (2012). Eine Anleitung zur Weltverbesserung. In Kapferer, E., Koch, A., Kühn, N., Sedmak, C., eds., Sozialatlas Lungau. Ideen und Projekte für ein besseres Zusammenleben (pp. 6-7). Wien: Mandelbaum.

[14] Sedmak, C., Fanninger, J., Suntinger, M. (2012). Tu was, dann tut sich was. Idee und Konzept des Sozialfestivals. In Kapferer, E., Koch, A., Kühn, N., Sedmak, C., eds., Sozialatlas Lungau. Ideen und Projekte für ein besseres Zusammenleben. Wien: Mandelbaum.

[15] Statistik Austria Bundesanstalt Statistik Österreich (2010). Arbeitskräfteerhebung 2009. Ergebnisse des Mikrozensus. Wien: Verlag Österreich $\mathrm{GmbH}$.

[16] Statistik Austria Bundesanstalt Statistik Österreich (2011). Bevölkerungs- vorausschätzung 2011-2050 sowie Modellrechnung bis 2075 für Österreich (Hauptszenario). Wien. 
[17] Statistik Austria Bundesanstalt Statistik Österreich (2012). Publikationen und Services. Ein Blick auf die Gemeinden. Steiermark. Eisenerz und Leoben. Online: www.statistik.at/blickgem/gemList.do?bdl=6 (15.10.2012).

[18] Statistik Austria Bundesanstalt Statistik Österreich (2012). Bevölkerungsstand 1.1.2012. Wien: Verlag Österreich $\mathrm{GmbH}$.

[19] Steiner, M. (2002). Vom Wandel in Vergangenheit und Gegenwart. Die wirtschaftliche Entwicklung der Steiermark seit 1945. In Ableitinger, A., Binder, D., eds., Geschichte der österreichischen Bundesländer seit 1945. Steiermark (pp. 127-234). Wien, Köln, Weimar: Böhlau Verlag.

[20] Verein Steirische Eisenstraße (2012). Portal Eisenstraße. Steirische Eisenstraße. Karte. http://www.eisenstrasse.co.at/portal/index.php?id=18 (12.11.2012). 